\title{
ANALISIS PENGGUNAAN MEDIA PEMBELAJARAN DITINJAU DARI PEMAHAMAN KONSEP PADA MATERI VOLUME BENDA PUTAR METODE KULIT TABUNG MAHASISWA PENDIDIKAN MATEMATIKA
}

\author{
Febi Sanjaya \\ Program Studi Pendidikan Matematika FKIP Universitas Sanata Dharma \\ Paingan, Maguwoharjo, Depok, Sleman, Yogyakarta 55282 \\ Email: febi@usd.ac.id
}

\begin{abstract}
This study aims to find out the understanding of the concept of mathematics education students. This research is descriptive with qualitative and quantitative approaches using instruments in the form of questionnaires and student worksheets (LKPD). The subject of this study was a student of Mathematics Education Sanata Dharma University class C who was studying Integral Calculus. From the results of the study, it can be concluded that $80 \%$ of students are helped by learning media, 52\% of students are in the category of quite understand and $48 \%$ of students are in the category of understanding. Furthermore, the results of the LKPD obtained 55\% of the group mastered the overall concept, and 45\% of the group still did not fully master the whole concept. Some of the reasons for the help of students in understanding the concept by using the media are: (1) the presentation of materials in the learning media is clear and coherent (2) images that facilitate understanding, (3) learn the concepts and practice questions first (4) presentation of materials and simple methods, (5) the mediafacilitate understanding.
\end{abstract}

Keywords: concept understanding, integral calculus, learning media

\begin{abstract}
ABSTRAK
Penelitian ini bertujuan untuk mengetahui pemahaman konsep mahasiswa pendidikan matematika. Penelitian ini bersifat deskriptif dengan pendekatan kualitatif dan kuantitatif dengan menggunakan instrumen berupa kuesioner dan Lembar Kerja Peserta Didik (LKPD). Objek dari penelitian ini adalah mahasiswa Pendidikan Matematika Universitas Sanata Dharma kelas $\mathrm{C}$ yang sedang menempuh mata kuliah Kalkulus Integral. Dari hasil penelitian dapat disimpulkan bahwa $80 \%$ mahasiswa terbantu dengan media pembelajaran, $52 \%$ mahasiswa berada pada kategori cukup paham dan $48 \%$ mahasiswa berada pada kategori paham. Selanjutnya hasil dari LKPD diperoleh 55\% kelompok menguasai konsep keseluruhan, dan 45\% kelompok masih belum sepenuhnya menguasai keseluruhan konsep. Beberapa penyebab terbantunya mahasiswa dalam memahami konsep dengan menggunakan media tersebut yaitu: (1) penyajian materi dalam media pembelajaran tersebut jelas dan runtut, (2) gambar yang memudahkan pemahaman, (3) belajar konsep dan latihan soal terlebih dahulu (4) penyajian materi dan metode yang sederhana, dan (5) media tersebut memudahkan pemahaman.
\end{abstract}

Kata kunci: kalkulus integral, media pembelajaran, pemahaman konsep;

\section{PENDAHULUAN}

Kalkulus Integral merupakan salah satu mata kuliah yang wajib ditempuh oleh mahasiswa Pendidikan matematika. Mata kuliah ini berisi beberapa topik integral yang akan 
mereka ajarkan di Sekolah Menengah Atas (SMA) sederajat seperti integral tertentu, integral parsial, metode substitusi, luas daerah, dan volume benda putar. Salah satu materi yang tidak mudah dipahami adalah topik volume benda putar. Meskipun topik ini sudah dipelajari mahasiswa ketika SMA, tidak berarti bahwa mereka sudah siap dan berhasil untuk menerima materi ini kembali.

Beberapa penelitian menunjukkan bahwa integral merupakan materi yang tidak mudah dipahami. Banyak siswa kesulitan untuk menyelesaikan persoalan-persoalan terkait integral. Susilo dkk (2019) dalam penelitiannya menunjukkan bahwa terdapat beberapa kesulitan yang muncul dalam pembelajaran itegral, diantaranya kesulitan dalam menggambar grafik, kesulitan dalam menentukan daerah yang dicari luasnya, kesulitan dalam menentukan batas integral, kesulitan dalam menggunakan rumus integral, dan kesulitan dalam memahami integral. Monariska (2019) menemukan bahwa salah satu faktor penyebab kesulitan belajar mahasiswa pada materi integral adalah lemahnya pemahaman mahasiswa terhadap konsep teorema dasar kalkulus.

Sanjaya (2020) pada penelitiannya terhadap mahasiswa Universitas Sanata Dharma mengindikasikan bahwa kurang dari $10 \%$ mahasiswa yang siap menerima topik ini kembali. Ada beberapa penyebab hal tersebut, di antaranya adalah visual benda tidak mudah untuk dibayangkan dan konsep yang belum begitu dipahami. Volume benda putar dapat dihitung menggunakan metode cakram, cincin, dan kulit tabung. Sebagian besar mahasiswa mengalami kesulitan pada metode kulit tabung. Selain itu, berdasarkan pengalaman peneliti di tahun 2019, hasil belajar mahasiswa Universitas Sanata Dharma kelas C pada topik volume benda putar belum baik, 62\% nahasiswa masuk minimal kategori cukup baik, bahkan hanya $22 \%$ mahasiswa minimal masuk kategori baik.

Media pembelajaran dapat dipahami sebagai media yang digunakan dalam membantu proses untuk mencapai tujuan pembelajaran. Menurut Sadiman dkk (2011), media adalah segala sesuatu yang dapat digunakan untuk menyalurkan pesan dari pengirim ke penerima sehingga dapat merangsang pikiran, perasaan, perhatian dan minat serta perhatian siswa sedemikian rupa sehingga proses belajar terjadi. Arsyad (2010) mengatakan hal serupa, yakni, komunikasi memegang peranan penting dalam proses pembelajaran, sehingga media pembelajaran yang sebenarnya juga menjadi media komunikasi berperan penting dalam menyalurkan pesan pembelajaran. Peran penting media pembelajaran tersebut sejalan dengan penuturan Mujiono (1994) yang menyebutkan bahwa media dan sumber belajar merupakan salah satu dari 4 komponen penting dalam kegiatan pembelajaran selain bahan ajar, suasana belajar, dan pendidik sebagai subjek pelajaran. Fungsi kognitif media pembelajaran sendiri menurut Levie dan Lentz (1982) adalah mempermudah memahami dan mengingat informasi.

Beberapa penelitian terkait Kalkulus dengan menggunakan media sudah banyak dilakukan dan mendukung apa yang disampaikan Levie dan Lentz (1982). Mustafidah dan Aryanto (2010) mengembangkan media pembelajaran digital interaktif. Pengembangan media tersebut menghasilkan peningkatan aktivitas siswa dan peningkatan hasil belajar. Hasil penelitian lain terkait media dan Mata Kuliah Kalkulus dilakukan oleh Sriyatun (2016). Dengan menggunakan pembelajaran kooperatif yang dilengkapi media pembelajaran power point interaktif beranimasi diperoleh hasil peningkatan hasil belajar. Oleh karenanya media pembelajaran yang tepat, menurut penulis dapat mengatasi permasalahan pemahaman volume benda putar. 


\section{METODOLOGI PENELITIAN}

Penelitian yang digunakan yaitu penelitian deskriptif dengan pendekatan kuantitatif dan kualitatif. Penelitian ini dilaksanakan di Program Studi Pendidikan Matematika Universitas Sanata Dharma. Objek penelitian ini adalah mahasiswa Program Studi Pendidikan Matematika yang mengambil mata kuliah Kalkulus Integral kelas C, yang berjumlah 33 orang. Kelas ini dipilih dikarenakan kemampuan kognitif mahasiwanya beraneka ragam, dari yang sangat baik hingga sangat kurang.

Teknik pengumpulan data yang digunakan adalah pengisian kuesioner dan pengerjaan Lembar Kerja Peserta Didik (LKPD). Pengerjaan LKPD dilakukan pada pertemuan pertama topik metode kulit tabung, sedangkan kuesioner diberikan pada akhir pembelajaran metode kulit tabung. Pada penelitian ini, media pembelajaran yang digunakan adalah LKPD yang dilengkapi diktat dan video pembelajaran. Media tersebut dideskripsikan berdasarkan kuesioner pendapat peserta, untuk Lembar Kerja Peserta Didik akan ditambahkan analisis hasil pekerjaan mahasiswa.

\section{HASIL DAN PEMBAHASAN}

\subsection{Pelaksanaan Pembelajaran}

Penelitian ini dilaksanakan dalam dua pertemuan. Dikarenakan adanya pandemi Covid 19 maka pertemuan dilaksanakan secara daring. Pertemuan pertama dilakukan melalui aplikasi grup Whatsapp sedangkan pertemuan kedua dengan zoom. Sebelum pertemuan kelas dosen sudah membagi mahasiswa dalam kelompok yang masing-masing berjumlah 3 atau 4 orang. Kelompok dibuat sedemikian hingga kemampuan kognitif masing-masing kelompok berimbang. Dosen juga memberikan diktat dan video pembelajaran untuk dipelajari sehingga pada jadwal pertemuan kelas mahasiswa dapat fokus berdiskusi dalam kelompok.

Pada pertemuan pertama dosen membagikan LKPD untuk dikerjakan dalam kelompok dan dikumpulkan pada akhir pembelajaran. Karena kesalahan teknis ternyata tidak semua mahasiswa dapat melihat video yang dibagikan sebelum pertemuan. Hal ini berakibat pada LKPD yang tidak terselesaikan. Oleh karena itu dosen memberikan toleransi waktu untuk pengumpulan LKPD. Pada pertemuan ini tidak terjadi diskusi materi antara mahasiswa dan dosen dikarenakan dosen ingin mengetahui pemahaman konsep mahasiswa dari bahan-bahan yang sudah diberikan.

Pada pertemuan kedua dilakukan diskusi hasil dari LKPD yang telah dikumpulkan melalui zoom. Dosen meminta beberapa kelompok secara acak untuk mempresentasikan hasil pekerjaannya. Tidak semua soal pada LKPD dibahas pada pertemuan ini, hanya perwakilan soal dengan konsep berbeda saja. Pada akhir setiap presentasi, dosen memberikan kesimpulan dan memberikan penguataan konsep agar mahasiswa lebih paham. Setelah presentasi selesai diberikan beberapa persoalan lain untuk dibahas di grup Whatsapp. Pada akhir pertemuan dosen memberikan tautan yang berisi kuesioner melalui google form.

\subsection{Hasil Penelitian dan Analisis Data}

Kuesioner yang diberikan bersifat tidak wajib sehingga hanya diisi oleh 25 dari 33 (79\%) mahasiswa. Kuesioner diberikan setelah dua pertemuan untuk materi kulit tabung selesai. Kuesioner berbentuk pertanyaan terbuka. Ada dua hal yang ditanyakan pada kuesioner tersebut yaitu tentang keterbantuan mereka terhadap media pembelajaran (LKPD yang dilengkapi diktat dan video pembelajaran) dan pemahaman mereka terhadap penggunaan media pembelajaran tersebut. 
Hasil kuesioner menunjukkan bahwa 5 dari 25 atau 20\% mahasiswa tidak merasa terbantu dengan media pembelajaran yang diberikan LKPD yang dilengkapi diktat dan video pembelajaran. Beberapa alasan yang menyebabkan hal tersebut adalah video pembelajaran yang kurang dimengerti karena menggunakan bahasa Inggris dan kurangnya penjelasan dari dosen. Sedangkan sisanya, 20 dari 25 atau $80 \%$ mahasiswa merasa terbantu dengan bahan pembelajaran. Dari hasil tersebut diperoleh beberapa penyebab yaitu:

a. Penyajian materi dalam media pembelajaran tersebut jelas dan runtut

b. Gambar pada diktat yang memudahkan pemahaman

c. Belajar konsep dan latihan soal terlebih dahulu

d. Penyajian materi dan metode yang sederhana

e. Media tersebut memudahkan pemahaman

Selain itu, ada 2 hal pendukung yang membuat mereka terbantu dengan media yang diberikan, yaitu diskusi kelompok dan penjelasan dosen pada pertemuan kedua. Akan tetapi beberapa mahasiswa yang terbantu tersebut juga mengeluhkan video yang menurut mereka kurang membantu sehingga mereka menggunakan video lain sebagai alternatif.

Selanjutnya terkait pemahaman mereka terkait topik volume kulit tabung menggunakan media tersebut, pada skala 1-5 diperoleh hasil sebagai berikut.

Tabel 1. Pemahaman Mahasiswa

\begin{tabular}{clc}
\hline Skala & \multicolumn{1}{c}{ Kategori } & Banyak Siswa \\
\hline 1 & Sangat Tidak Paham & 0 \\
2 & Tidak Paham & 0 \\
3 & Cukup Paham & 13 \\
4 & Paham & 10 \\
5 & Sangat Paham & 2 \\
\hline
\end{tabular}

Dari Tabel 1, meskipun diperoleh hasil bahwa $0 \%$ mahasiswa yang tidak paham, peneliti belum puas dengan hasil tersebut. Hal ini dikarenakan peneliti menyimpulkan bahwa hanya 12 dari 25 , atau $48 \%$ mahasiswa yang benar-benar paham terhadap topik volume kulit tabung sedangkan $52 \%$ sisanya masih pada kategori cukup paham.

Hasil Tabel 1, menurut peneliti didukung oleh apa yang mereka kerjakan dalam kelompok, di mana 6 dari 11 kelompok terlihat menguasai konsep meskipun ada beberapa yang kurang baik alur dalam konsepnya. Sedangkan 5 dari 11 sisanya terlihat kurang memahami konsep pada soal tertentu. Berikut beberapa contoh pekerjaan mereka. 


\section{Tabel 2. Contoh Pemahaman Konsep dari Hasil Pekerjaan Kelompok}

No.

1 .

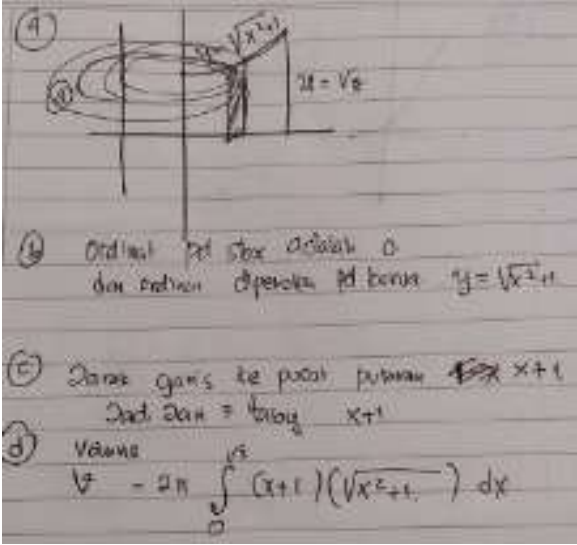

2.

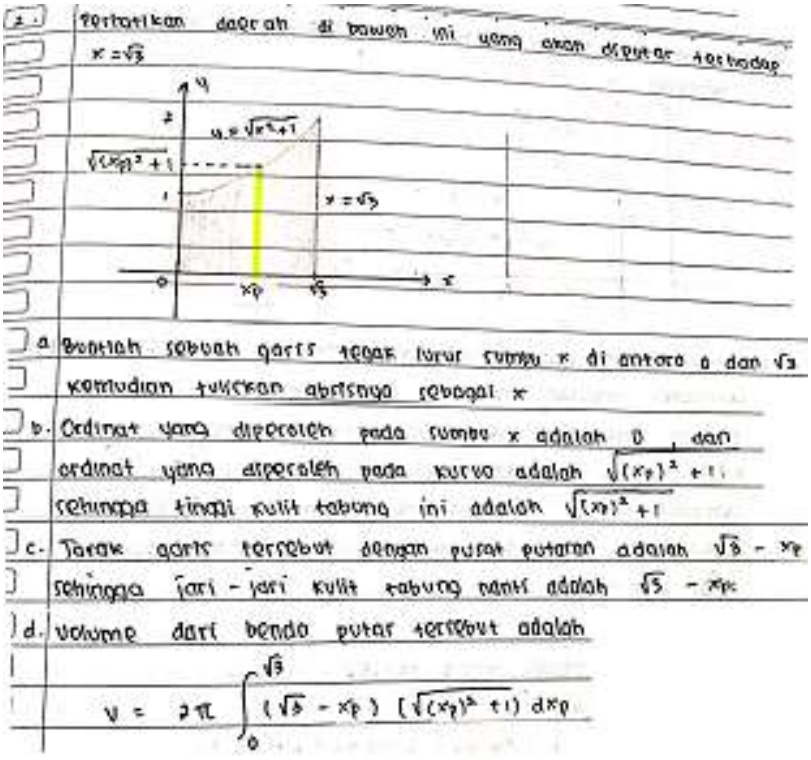

Penjelasan

Hasil disamping menunjukkan bahwa kelompok tersebut dapat memahami konsep untuk menentukan volume kulit tabung tanpa ada kesalahan.

Hasil di samping menunjukkan bahwa kelompok tersebut dapat memahami konsep untuk menentukan volume kulit tabung. Hanya saja jika dicermati lebih lanjut, ada proses yang kurang tepat, yaitu mengubah $x$ dengan

memunculkan $x_{p}$. 


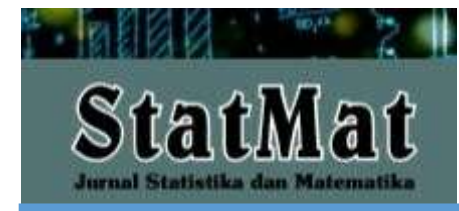

3. 2. Perhakkan daerah dibawah ind yang akan diputar terhadap $x=\sqrt{3}$

a.) Buat garir tegak lutur sumbu $x$ drantara o sampai $\sqrt{3}$

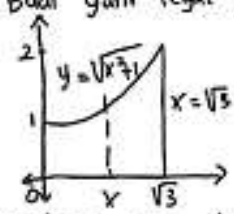

b) Ordinat yang diperdeh pada setmbu $x$ adalah 0 ordnat yang drperdeh pada kurva adalah $\sqrt{x^{2}+1}$ Sehingga tinggi kulut tabung addlah. $y=\sqrt{x^{2}+1}-0$

$y=\sqrt{x^{2}+1}$

c)

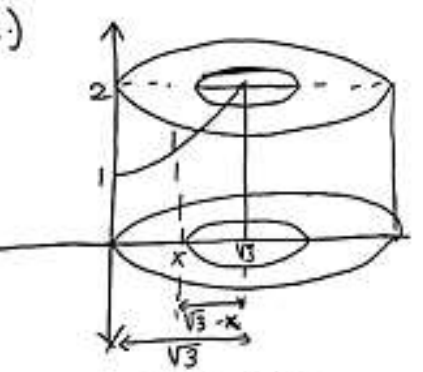

d.) Volume benda putar

$$
\begin{aligned}
V & =2 \pi \int_{a}^{b} x f(x) d x \\
& =2 \pi \int_{0}^{\sqrt{3}}(\sqrt{3}-x)\left(\sqrt{x^{2}+1}\right) d x
\end{aligned}
$$

4.

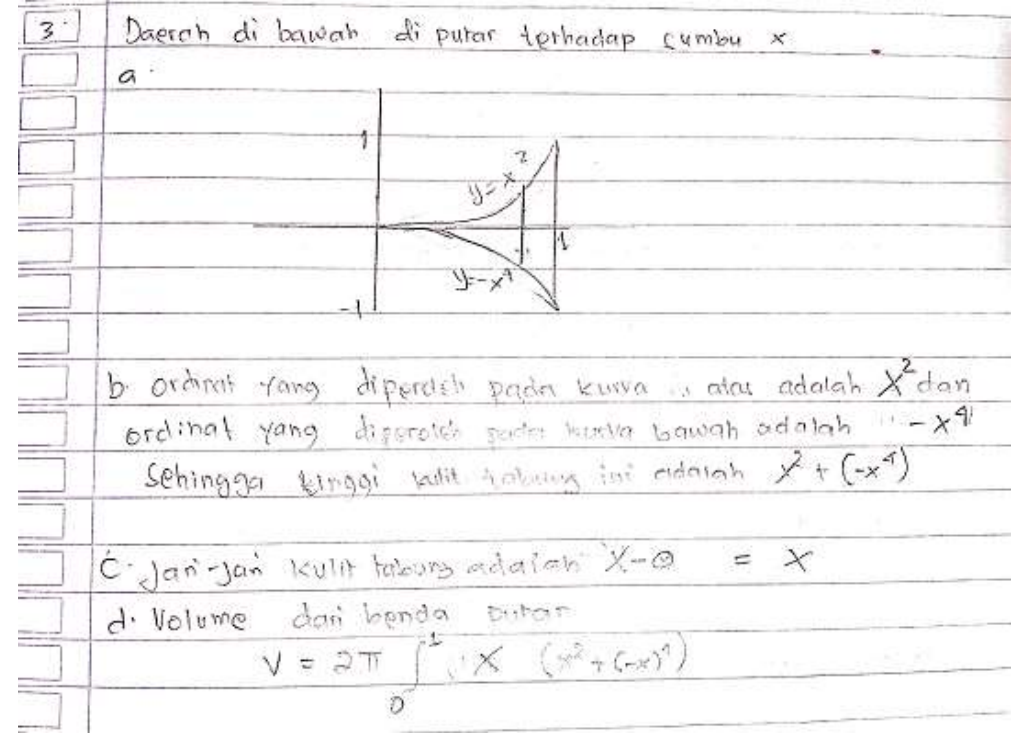

Hasil di samping menunjukkan bahwa kelompok tersebut kurang memahami konsep untuk menentukan volume kulit tabung. Kesalahan konsep yang terlihat adalah jari-jari kulit tabung yang seharusnya $\sqrt{3}-x$ tetapi juga tertulis $\sqrt{3}-0=\sqrt{3}$. Artinya mereka masih ragu konsep mana yang tepat.

Hasil di samping menunjukkan bahwa kelompok tersebut kurang memahami konsep untuk menentukan volume kulit tabung. Kesalahan konsep yang terlihat adalah dalam menentukan tinggi kulit tabung yang seharusnya $x^{2}-$ $\left(-x^{4}\right)$ tetapi malah ditulis $x^{2}+\left(-x^{4}\right)$ Artinya mereka masih kurang paham akan konsep jarak. 


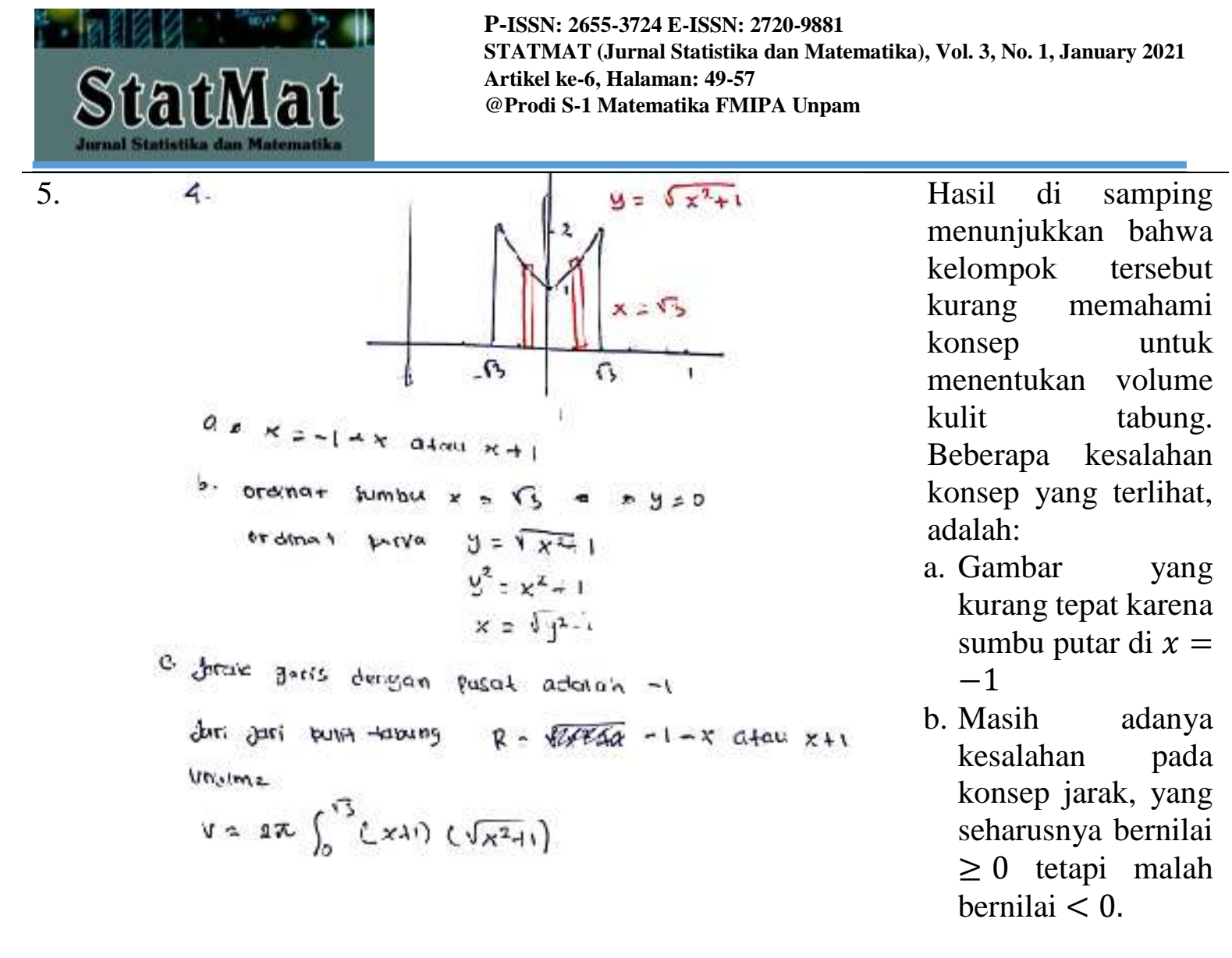

\subsection{Pembahasan}

Dari hasil kuesioner diperoleh bahwa $80 \%$ mahasiswa terbantu dengan media pembelajaran, 52\% mahasiswa berada pada kategori cukup paham dan $48 \%$ mahasiswa berada pada kategori paham. Hal ini didukung oleh hasil pekerjaan mereka pada LKPD di mana 55\% kelompok terlihat menguasai konsep keseluruhan, sedangkan sisanya, 45\% kelompok masih belum sepenuhnya menguasai keseluruhan konsep. Menurut peneliti, ini merupakan hasil yang positif, saling melengkapi, dan tidak ada perbedaan yang cukup signifikan. Dengan penguasaan konsep yang baik peneliti meyakini akan meningkatkan hasil belajar mahasiswa juga. Hal ini sesuai dengan apa yang dikatakan Kemp dan Dayton (1985) bahwa media pembelajaran dapat meningkatkan kualitaas hasil belajar siswa.

Temuan lain yang diperoleh dari penelitian ini adalah terdapat 2 hal pendukung yang membuat mereka terbantu dengan media yang diberikan, yaitu diskusi kelompok dan penjelasan dosen. Diskusi kelompok ini sebenarnya baik jika bisa untuk ditelusuri lebih dalam untuk mengetahui prosesnya, hanya saja pembelajaran daring membuat hal tersebut tidak mudah untuk dilakukan. Penjelasan dosen menurut peneliti membuat mahasiswa lebih yakin dengan konsep yang sudah dipahami dan membuat mahasiswa lebih jelas jika konsepnya masih bingung.

Ada juga temuan yang dirasa negatif oleh peneliti yaitu adanya mahasiswa yang terbantu dengan media pembelajaran tetapi mengeluhkan video yang menurut mereka kurang membantu sehingga mereka menggunakan video lain sebagai alternatif. Peneliti menyadari hal ini dikarenakan video dipilih dari Youtube yang menurut peneliti mudah dipahami, tetapi kurang memerhatikan kesinkronannya dengan LKPD. Selain itu video dengan bahasa Inggris ini menjadi ganjalan mahasiswa dalam mempelajar konsep. Hal ini menurut peneliti merupakan alasan yang kurang relevan dengan era globalisasi saat ini juga mengingat bahasa Inggris dalam matematika juga tidak terlalu perlu banyak kosakata. 
Dari Tabel 2, terlihat bahwa masih terdapat beberapa kekurangan pemahaman konsep yang terjadi pada penentuan volume dengan metode kulit tabung, diantaranya adalah:

i) Kesalahan menggambarkan benda putar.

Pada bagian ini mereka terlihat kurang memperhatikan pusat putaran benda putar. Pada contoh di atas, pusat yang seharusnya berada di $x=-1$ tetapi malah diputar dengan pusat $x=0$.

ii) Kurangnya pemahaman konsep dalam menentukan 'tinggi'.

Pada bagian ini terlihat bahwa konsep tinggi yang dilakukan bukan fungsi kurva atas dikurangi fungsi kurva bawah tetapi malah menjumlahkan fungsi kurva atas dengan fungsi kurva bawah.

iii) Kurangnya pemahaman konsep dalam menentukan 'jari-jari'.

Dari contoh di atas, yang dihitung adalah $\sqrt{3}-0=\sqrt{3}$ padahal seharusnya jari-jari masih dalam variabel $x$.

iv) Kurangnya pemahaman konsep 'jarak'.

Pada bagian ini konsep jarak yang seharusnya tidak negatif kurang diperhatikan sehingga dituliskan hasil negatif.

\section{SIMPULAN}

Dari hasil penelitian dapat disimpulkan bahwa bahwa $80 \%$ mahasiswa terbantu dengan media pembelajaran, 52\% mahasiswa berada pada kategori cukup paham dan $48 \%$ mahasiswa berada pada kategori paham. Selanjutnya hasil dari LKPD diperoleh 55\% kelompok menguasai konsep keseluruhan, dan 45\% kelompok masih belum sepenuhnya menguasai keseluruhan konsep. Beberapa penyebab terbantunya mahasiswa dalam memahami konsep dengan menggunakan media tersebut yaitu:

a. Penyajian materi dalam media pembelajaran tersebut jelas dan runtut

b. Gambar yang memudahkan pemahaman

c. Belajar konsep dan latihan soal terlebih dahulu

d. Penyajian materi dan metode yang sederhana

e. Media tersebut memudahkan pemahaman

Selain itu terdapat beberapa kekurangan pemahaman konsep yang terjadi pada penentuan volume dengan metode kulit tabung, diantaranya adalah:

a. Kesalahan menggambarkan benda putar.

b. Kurangnya pemahaman konsep dalam menentukan 'tinggi'.

c. Kurangnya pemahaman konsep dalam menentukan 'jari-jari'.

d. Kurangnya pemahaman konsep 'jarak'.

\section{DAFTAR PUSTAKA}

Arsyad, A. (2010). Media Pembelajaran. Jakarta: Rajawali Pers.

Kemp, J.E. dan Dayton, D.K. (1985). Planning and Producing Instructional. Media. Cambridge: Harper \& Row Publishers, New York.

Levie, W. H., \& Lentz, R. (1982). Effects of text illustrations: A review of research. Educational Communication \& Technology Journal. 30(4): 195-232.

Monariska, E. (2019). Analisis Kesulitan Belajar Mahasiswa pada Materi Integral. Jurnal Analisa. 5(1): 9-19.

Mujiono. (1994). Belajar dan Pembelajaran. Jakarta: Dirjen Dikti Depdikbud

Mustafidah, H. dan Aryanto, D. (2010). Pengembangan Media Pembelajaran Digital 
Interaktif Kalkulus-II dalam Peningkatan Prestasi Belajar Mahasiswa. Jurnal Techno. 11(2): $84-93$.

Sadiman, dkk. (2011). Media Pendidikan, Pengertian, Pengembangan,dan Pemanfaatannya. Jakarta: PT. Raja Grafindo Persada.

Sanjaya, F. (2020). Kemampuan Awal Kalkulus Integral Mahasiswa Pendidikan Matematika Kelas B Universitas Sanata Dharma. Jurnal StatMat. 2(2): 189-197.

Sriyatun, S. (2016). Peningkatan Pemahaman Konsep Integral Tak Tentu Melalui Pembelajaran Kooperatif Berbantuan Media Pembelajaran Power Point Interaktif Beranimasi. Seminar Nasional Matematika X Universitas Negeri Semarang. 137-145.

Susilo, B. E., Darhim, dan Prabawanto, S. (2019). Kesulitan Belajar Mahasiswa pada Materi Aplikasi Integral untuk Luas Daerah dalam Perspektif Disposisi Matematis. Jurnal Kreano. 10(1): 86-93. 